\title{
ЧИСЕЛЬНЕ ОБЧИСЛЕННЯ ОПТИМАЛЬНОГО КЕРУВАННЯ СТАДІЇ ВІДПАЛУ ПОЛІМЕРАЗНО-ЛАНЦЮГОВОЇ РЕАКЦІЇ
}

А. С. Сверстюк

ДВНЗ «Тернопільський державний медичний університет імені І. Я. Горбачевського МОЗ України»

\section{NUMERICAL CALCULATION OF OPTIMAL CONTROL STAGES ANNEALING POLYMERASE CHAIN REACTION}

\author{
A. S. Sverstyuk
}

SHEI «Ternopil State Medical University by I. Ya. Horbachevsky of MPH of Ukraine»

Вступ. Полімеразна ланцюгова реакція (ПЛР) широко використовується в біологічній і медичній практиці для клонування генів, діагностики мутацій, виділення нових генів, секвенування, для створення і визначення генетично модифікованих організмів.

Для ефективного проведення ПЛР необхідно забезпечити багатостадійний циклічний режим зміни температури.

Метою даної доповіді $є$ дослідження керованості стадією відпалу ПЛР.

Результати. У досліджуваній моделі використано рівняння Арреніуса, що враховує залежність швидкості реакції від абсолютної температури. Застосовано принцип максимуму Понтрягіна до задачі оптимального керування стадією відпалу та сформульовано необхідну умову оптимальності. Розроблено прямий метод чисельного розв'язаня задачі оптимального керування стадією відпалу, який реалізовано в пакеті Јava-класів.

Висновок. Отримані результати чисельного моделювання задачі оптимального керування стадією відпалу ПЛР допоможуть мінімізувати необхідний час реалізації даної стадії. 